\title{
THE JUSTIFICATION FOR APPLICATION AND DEVELOPMENT TRENDS OF NON-CONVENTIONAL RODENTICIDES IN PROTECTION OF ALFALFA FROM RODENTS
}

\author{
M. Vukša ${ }^{1}$, G. Jokić ${ }^{1}$, S. Đedović ${ }^{1}$, P. Vukša ${ }^{2}$, B. Stojnić ${ }^{2}$ \\ ${ }^{1}$ Institute of Pesticides and Environmental Protection, 31 B Banatska, Zemun, Serbia \\ ${ }^{2}$ Faculty of Agriculture, Institute of Phytomedicine, Nemanjina 6, Zemun, Serbia \\ Corresponding author: Marina.Vuksa@pesting.org.rs \\ Review paper
}

\begin{abstract}
This paper presents the harmful rodents in alfalfa in Serbia in the first decade of this century. We also review the products registered and assessed the efficiency of conventional (acute) rodenticides, anticoagulant and rodenticides based on environmentally friendly active ingredients. In addition to anticoagulants of second generation, whose mechanism of action is based on a synthesis of the factors preventing blood coagulation, in the latest of the eighties, and in early of nineties introduced products based on vitamin D3cholecalciferol. Their mechanism of action is based on the mobilization of calcium from bone and tissue and calcification of blood vessels, kidney, liver, heart muscle leading to delays in the work of these bodies. The last decade of the last century have been recorded and products based on trace element selenium (Se), the mechanism of action is based on the replacement of thiol functional enzymes SS groups. Also presents the possibility of application of ecological cellulose product in the field. In the world, so far, cellulose based rodenticides are only registered in municipal buildings. Its mechanism of action is based on interference with the absorption of water leading to dehydration in rodents. Rodents do not develop resistance to products based on vitamin D3 and selenium, a cellulose product is favourable toxicological and eco-toxicological point.
\end{abstract}

Key words: alfalfa, rodenticides, cellulose, sodium selenite, chemosterilants, biorodenticides

\section{Introduction}

Unlike wheat, which is used in feeding more than $70 \%$ of the population of the globe (Glamočlija, 1997), alfalfa is the most important forage crop (Štrbac et al.,1996). The importance of developing alfalfa livestock, primarily 
based on the high potential for biomass yield. High yields of hay in a multi year period of exploitation with a relatively low investment make it happy and very profitable cultivated species. Variable gene fund provides good alfalfa adaptation to changing environmental conditions. It is used for livestock feed in various forms, most commonly as hay, and dried in the form of briquettes as silage, haylage or grazing. The importance of alfalfa increased by the fact that the application of appropriate methods of conservation, biomass produced, with minimal losses nutritional value, can be used all year round. The process of biological nitrogen fixation alfalfa provides not only economic, but also a very high ecological significance and increasingly crucial role in sustainable and organic agriculture (Radović et al., 2009). In Serbia, alfalfa is grown on about 200000 ha (Republički zavod za statistiku, 2011). The area has more than 40 species and subspecies nearly as rodents and all belong to the genus Rattus. Their number depends on several factors, such as the physiological state of individuals in a population, microclimate, habitat and food sources (Djukić et al., 2005).

Demonstrated adaptability to life in various conditions and types of open habitats, ecological preferences developed in relation to the most important environmental factors (humidity, type of substrate), omnivorousity, high breeding potential and cyclic reproduction of the basic characteristics of field rodents, which enable the optimal existence and applicable constitute the main problem during their suppression. With favourable growing conditions during the year of alfalfa, a high potential of product and great quality plant mass to generate favourable conditions for the settlement and the formation of colonies of rodents. This is confirmed by the results of the research of Babinska to which field vole, number 220-410 animals per acre of alfalfa, can cause economic losses of $35.6 \%$ (Babinska-Werka, 1979). Field rodents caused damage from sowing to harvest. In some areas in Vojvodina, re-sowing of crops was recorded (Djukic et al., 2005). In Serbia, came to the considerable growth of pest rodents. In some regions, the number was in the high category IV-V and overlapping values (Vukša and Forgić, 2003, 2006; Vukša et al., 2010).

These data indicate that rodents are one of the key factors in limiting the yield, and that their control is one of the most important requirements for cost-effective production of alfalfa. In order to achieve this, it is not only a good knowledge of rodent biology, but also the selection of appropriate methods of control. The results of research and practical experience indicate that the process is based on the suppression of taking preventive measures and direct, singly or in combination (Hrgović et al., 1991; Buckle and Smith, 1994; Jacob, 2003). The best effects are achieved by proper selection and application of rodenticide technology, along with the necessary knowledge and appreciation of the characteristics of rodents (Prakash, 1998; Singleton et al., 1999). Unlike bromadiolone, brodifacoum and vitamin D3, which have been in use since 70-ies of the last century and which are available in numerous literature data (Meehan 1978; Lund, 1988; Hrgović et al., 
1991; Kataranovski and Kataranovski, 1997; Husinec et al., 2002), the introduction of the use of sodium selenite and cellulose, which is the small number of available literature data, which began earlier this century. Due to the significant development of ecological approach in growing crops, but also because of the conditions and restrictions of existing applications, the need for finding, developing and using environmentally friendly rodenticides with the intention of improving the protection of plant production. In this paper we analyze the number of rodents in Serbia in the last decade of alfalfa. Then, a review of the products registered for their control with different mechanisms of action. The aim of this paper is to present the development trends of new, non-conventional rodenticides, their advantages and disadvantages compared to conventional rodenticides. Evaluate the efficacy of classical major (acute) rodenticides, anticoagulant rodenticides and rodenticide based on active environmentally friendly materials.

Significant economic types and their abundance. Common vole (Microtus arvalis Pallas, 1778) is the most common Eurasian otter (Ricankova et al., 2007) in alfalfa, where we start with the primary habitats (meadows, pastures, and fallow land) (Myllymäki, 1977; Jacob, 2003). The most abundant species is the rodents in agricultural areas in Serbia (Petrov and Ruzic, 1985; Mikes and Habijan-Mikes, 1986; Djukic et al., 2005). At the time of germination and emergence feeds on seeds and seedlings would mature parts of herbaceous plants, while in the winter feeding and other activities causing damage to the roots. Destroy a colony of about $15 \mathrm{~m}^{2}$ average crop.

Field mice (Apodemus spp.). Belong to the group of economically important pests occasionally a large number of plants. On alfalfa fields, the most significant damage occurring during the winter, when the ground damages the roots of the plant. In the period before the harvest gender truncated branches and cause significant losses in seed production (Petrov and Ruzic, 1983; Mikes and HabijanMikes, 1986; Stenseth, 2003; Djukic et al., 2005). In the area of Srem the most numerous kind is A.agrarius (Vukša, 2005; Kereši et al., 2005).

Hamster (Cricetus cricetus) represents the major economic field rodents. Damages above and below ground parts of plants, fruits and seeds. Collect food for the winter (and a few dozen kilograms). During the spring of damage alfalfa, clover and small grains, and during the summer and early autumn, corn, sunflowers, sugar beets, potatoes, carrots and other plants (Wienhold et al., 1999; Nechay, 2000; Djukic et al., 2005; EU, 2009). In Vojvodina has repeatedly plagued by re-sowing large area under sunflower due gradation hamster 1996, 1997, and 2006 (Djukic et al. 2005; Vukša and Forgić, 2006).

Natural habitats of rodents. Rodents found in nature in habitats suitable for life and reproduction, and occupy a very important place in the food chain. Field rodents, particularly the most common types of $M$. arvalis have three types of agroecological habitats: reserves, storage, and unfavourable terrain. Reserves are open lands that are rarely or never treated (pastures, lawns, meadows, boundaries and 
levees) where field rodents naturally live and survive in small numbers in the most unfavourable conditions. Accumulation habitats are alfalfa, clover and small grains where rodents reach maximum abundance and population density. Unfavourable habitats are meadows, row crops, hemp, sand and underwater terrain, where they survive, but they do not reproduce, but migrate to more favourable areas.

Risk assessment and abundance. Determining the number of field rodents is of particular importance in the plots where the planned sowing seed crops. Before their prevention should be evaluated to determine the population size and species present transect method using C-30 (WHO) (Djukic et al., 2005) and threshold (Smith et al., 1975; EPPO, 2004). Approximate number of voles is estimated based on the number of active holes, and on the basis of field mice inlets. Rights abundance is determined by the conger hunting lines in isolated areas. Hamster population size is determined in late winter or early spring, when following a stream exiting this mode. As a threshold identification is taken 2-3 individuals, or active holes/ha. You should determine the size of a hamster in early June, after the completion of the cycle of reproduction, as well as the end of summer, before falling into hibernation. In all three cases, in addition to determination of the number and age distribution of the population and the state of genital mutilation of females was determined. The risk of rodents is based on data on the abundance of all species after overwintering and analyses of genitals that should be run in early spring, early and late summer and the autumn. They are overlapping for a number of reasons. Increased population size should be expected after a long and warm autumn, mild winter with long-lasting and deep snow cover, as well as during the warm and dry early spring. The availability of food, especially in the second half of vegetation contributes to increased numbers of rodents. A reduction of the number comes after a long and cold winter (C. cricetus), drainage channels. Rodent and can reduce predators, natural enemies, such as owls, eagles, buzzards, shrews, foxes, various parasites and diseases (Čamprag, 1980; Djukic et al., 2005). During our research, we followed rodent numbers in Vojvodina in the period from 19992011. The rodent numbers in Odžaci, Sombor, Kula, and Apatin Pancevo ranged from the third to the fourth category (medium to high). During autumn 2003 and spring of 2004 the rodent numbers were lower than previous years. The highest number recorded in 2005 in the area of Sremska Mitrovica, Sombor, Vrbas, Kula, Srbobran Bečej and Belgrade (Keresi et al., 2005). A stronger attack voles was recorded and 2009 (Vukša et al., 2010).

Preventive care. Protection from rodents is based on preventive measures and direct control of harmful rodents (Brooks and Row, 1987; Hrgović et al., 1991; Endepols, 2002; Lynwood and Sayed, 2002).

Intensive agrotechnical measures. The rodent numbers adversely affected by intensive tillage, timely sowing of autumn and the timeliness and quality of crops, destruction of crop residues. For example, early post harvest ploughed deep 
autumn ploughing and destroy the dens and hallways and hurt the young, changing the food destroys habitat, weeds, etc. (Čamprag, 1980; Djukic et al. 2005). Rodenticides and their use to control rodents used in a wide range of rodenticides, which differ in active substances, mechanisms of action, toxicity and formulation type (Brooks and Rowe; 1987; Kataranovski and Kataranovski, 1997). According to the origin rodenticide active ingredients are divided into synthetic and natural, obtained by separation from the natural substrate. In relation to the mechanism of action, rodenticides are heterogeneous compounds (Brooks and Rowe, 1987; Hrgović et al., 1991; Roberts and Hutson, 1999). With regard to toxicity, rodenticides are also heterogeneous. Substances are widely represented in the first group of poison (zinc phosphide), and substances that are not classified amongst toxic, cellulose. In our country, for commercial use in agriculture five chemical groups of compounds (coumarin, hydroxycoumarin, indanediones, sterols and inorganic phosphorus compounds) are registered with a total of eight different active substances (bromadiolone, flokumafen, warfarin, brodifacoum, hlorofacinon, vitamin D3 and zinc phosphide). Also, for the same purpose sodium selenite was registered (Janjic and Elezovic, 2010). A total of seven formulations: RB (ready to use bait) PB (lined baits), BB (block), AB (granular bait) GB (granular baits), PT (pellets), CB (dustable oil or concentrate for making baits).

Conventional fast-acting rodenticides - acute rodenticides. According to Hadler and Buckle (1994) and Roberts and Hutson (1999) fundamental properties of this group of rodenticides is to quickly demonstrate toxic effects after taking by mouse-like rodents. Therefore, these funds are often referred to as acute poisons or current. The first signs of poisoning and death of animals occur in a few minutes to 24 hours, depending on which product is used. The downside is that the acute rodenticides in small quantities pose a great threat to domestic and other useful animals and humans, which necessitates special precautions for their practical implementation. The lack of these products is the fact that in the case of poisoned rodents exhibit signs of toxicity in the form of cramps, screaming and abnormal behaviour in general, which disturbs, warned of the danger and scares off other individuals, creating the effect of fear of them offered poisoned food. A major drawback of acute poisons is that for some of them there is an appropriate antidote. Widest application in controlling rodent pests in alfalfa, in this group of rodenticides with vitamin D3 and zinc phosphide (WHO, 1988; Hrgović et al. 1991; Kamrin 1997).

Slow acting rodenticides. Introduction anticoagulant rodenticide anticoagulant early fifties of this century has been a considerable progress in controlling populations of rodent pests. These rodenticides are still the most widely used chemical substances in pest control in the country and abroad. Compared to the fast-acting rodenticides, these rodenticides in rodents do not cause fear of baits. Decoys are exposed for several days in a row, and the death of the bird species of the genus Apodemus and voles require a period of up to 12 days 
(Hrgović et al., 1991; Jokić at al 2010 b). All anticoagulant rodenticides, which are used in practice and indanedione derivatives hydroxycoumarin. Although differing in chemical structure, their physiological effect is the same action, preventing all. Their primary mode of action is antagonism compared to vitamin K1 epoxide through inhibition of reductase (Roberts and Hutson, 1999).

Chemosterilants use compounds that cause mutagenic effects of one form of genetic control, and if such compounds reduce fertility and increase mortality in the next litter, it acts as chemosterilants. Since steroid hormones as inhibitors of spermatogenesis are used estrogens and androgens. Also, the use of some nonsteroidal compounds may inhibit implantation, then induce abortion or interfere postreunion events. For now, much more is known about the physiological capabilities of chemosterilants than on the environmental aspects of their use in controlling rodents. The efficiency of the chemosterilants depends more on the biology and ecology of the appropriate types of harmful rodents, but it is necessary for the efficient use of lethal rodenticides. Chemosterilants rodents must be available immediately after the IUI or in early gestation. Just the fact that it requires extreme precision in determining the period of breeding animals, and is the biggest drawback of these compounds (March and Howard, 1970). Alphachlorchydrine mechanism of action: metabolic activation of alphachlorohydrine occurs oxalic acid which inhibits the metabolism of glucose and its degradation by glyceryl aldehyde, with the inhibitory effect on the growth and development of sperm is based on the inhibition of the enzyme aldehyde-glyceryl-3-phosphate dehydrogenase (Misic et al., 1991). Disposable eating more alpha-chlorhydrin except sterility, manifested a lethal effect on the rodents, which is caused by deposition of calcium oxalate crystals in the renal tubules and epididymis systems. The active ingredient is a racemic mixture of $\mathrm{R}$ and $\mathrm{S}$ alphachlorohydrine. Relatively small doses causing reduction in the number and motility of sperm, higher doses of testicular pathology and/or death. S-alphachorohydrine is converted to S-3-chloroacetaldehyde, which inhibits the enzymes work glyceryl aldehyde-3phosphate dehydrogenase enzyme essential for glycolysis sperm (Jones 1983; Jones and Cooper, 1999). Miller and Jelks (Jelks and Miller, 2001) found that the $\mathrm{R}$-enantiomer is responsible for toxicity of higher doses to the kidneys. The studies indicate that in vitro metabolic pathway via alpha-beta-chlorohydrine, chloraldehyde leads to beta-chloro lactal acid which results in slow formation of calcium oxalate kidney causing glomerulonephritis (Kalla and Chohan, 1980). The results of Sung et al. (2012) suggest that blocking alphachlorohydrine antioxidant defence system and spermatotoxicity derived from oxidative stress. Preparation Epiblok ${ }^{\circledR}$ rodenticides (1\% alphacholrohydrine to $5 \mathrm{~g}$ of bait in the bag: EPA registration number 42 882-E) registered for the control of Rattus norvegicus in and around the commercial / industrial / agricultural buildings, warehouses and similar facilities. According to the latest recommendations of HED facilities must be precisely defined, baits must be laid out in closed plastic containers and they 
must not come into contact with children, food and livestock. Bags of baits must also be specially marked. Preparations based on alphachlorohydrine were registered in the world and in Yugoslavia. Our studies showed very good efficacy against comensal rodents in the control of rodents in the area (Dunđerski and Vukša 1986, 1987a,b; Vukša et al., 2006). In Serbia there are no registered products based on chemosterilants.

Biorodenticides. On products based on bacteria in the world and in Europe from the late 19 th century to the early 60 -ies of the 20th century used on products based on bacteria Salmonella enterica serotype Enteridis var. Danysz, lysine negative phage type $6 \mathrm{a}$, when the number of recorded deaths in people forbidden. In addition, these drugs are produced and used in Central and South America, Africa and Asia (Cuba, Bolivia, Honduras, El Salvador, Guatemala, Peru, Costa Rica, Dominican Republic, Panama, Ecuador, Paraguay, Chile, Mexico, Nicaragua Anglola, Lebanon, Laos, Mongolia, China). Preparation BIORAT (Labiofarm Cuba) is produced in Cuba (Salmonella Enteridis, warfarin and rice grain) and is registered for use in many countries. This product does not bear the marks of risks to human health and has a specification that is pathogenic for animals (Schachter, 1998; Painter 2004). The mechanism of action enterotoxins induce lesions in the intestinal mucous membrane, allowing bacteria to enter the bloodstream and colonize target organs such as the heart, spleen, liver, kidneys and cause systemic infection. According to data Toschiguin (1979), Espino (1986) and Bykovski and Kandyvin (1988) or oral administration of very high doses of $S$. enteritidis var. Danysz leasing does not lead to negative symptoms of the disease of a single domestic animals (pigs, rabbits, sheep, horse, cat, dog, etc.). $S$. enteritidis var. Danysz lysine-negative strain did except for invasive species for the Muridae rodents and no serological responses in other animals, even at oral application.

Conventional rodenticides sodium selenite. According to the chemical classification, sodium selenite, as a sodium salt and selenious acid, is one of the most common forms of free selenium in nature (Anonymous, 2005). Sodium selenite $\left(\mathrm{Na}_{2} \mathrm{SeO}_{3}\right)$ was soon discovered to comprise rodenticidal compound. The early 21 st century in our country for the first time it was registered as a rodenticide for use in agriculture and communal hygiene. Presently, registered baits contain $0.1 \%$ sodium selenite. Registered products are classified in the second group of toxins (Janjic and Elezovic, 2010). Selenium compounds reduce the level of peroxide in the tissues breaking hydrogen peroxide action of enzymes containing selenium glutathione peroxidase. Animal studies indicate that the cytotoxicity of selenium result prooxidant catalytic activity selenite anions, which produce superoxide anions, hydrogen peroxide and other reactive metabolites. Methylation reactions in plants and animals, and enhance antioxidant defences along toxicity of selenium in various forms (Barceloux, 1999). Toxicity depends on the chemical form of selenium. Selenite is more toxic than selenate. Target organs are the 
respiratory tract, central nervous system, cardiovascular system, gastro-intestinal tract, skin. It is believed that the toxicity of selenium based on replacement of SH groups of functionally enzymes with S-S groups in the active sites in enzymes (Frenkel and Falvey, 1988, 1989). According to research Jacevic et al. (2006), orally applied sodium selenite causes cardiotoxic effects in laboratory mice. Acute oral LD50 of sodium selenite for the laboratory mouse strain Swiss Webster, and laboratory Wistar rats, was 9.79 , or $11.20 \mathrm{mg} / \mathrm{kg}$ (Jacevic et al., 2011). According to research Pletnikova (1970) the acute oral LD50 of sodium selenite for the laboratory mouse was 7 or $48 \mathrm{mg} / \mathrm{kg}$. Oral applied selenium is almost completely absorbed in the digestive system, $95-100 \%$. The process of absorption is controlled and homeostatic differences are observed in the absorption processes in rats with a deficiency or excess selenium when used for secondary toxic dose (Brown et al., 1972). Approximately $7-17 \%$ of selenite is converted to volatile forms, and the degree of volatility decreases with increasing concentration of sodium selenite. Selenite binds the cytosolic protein fraction cells. Sodium selenite in hepatocytes accumulated in two phases: an initial rapid process and the subsequent slower phase. Concentrations that lead to inhibition of $50 \%$ are 50 and 50 micromoles of sodium selenite. Maximum concentrations in all tissues was observed after 6 hours, and 48 hours in most of the body back to normal. Most tissue (75\%) showed an inverse degree of retention depending on the methods applied dose (Ryszka et al., 1994; Kinder et al., 1988; Park and Whanger, 1995). Benefits of sodium selenite as rodenticide are in the fact that the effect of lethality is achieved by entering single, and there is no risk of primary and secondary poisoning by eating dead rodents. There is no possibility of resistance, because the mechanism of action is based on inducing cell death and leads to environmental pollution. These preparations have so far shown good acceptability and effectiveness of the blocks and 78.51 to $88.91 \%$ grain baits and granules to control rodents in alfalfa (Vukša et al., 2006, 2009; Jokic et al., 2009a,b,c, 2010a). In Serbia has registered several preparations and formulations of the active ingredient for use in agriculture and communal hygiene.

Cellulose is a natural polymer generated by photosynthesis. It consists of glucose anhydride empirical formula $\left(\mathrm{C}_{6} \mathrm{H}_{10} \mathrm{O}_{5}\right)$ n. Cellulose belongs to a group of polysaccharides which are up to $80 \%$ of the dry matter of the plant world, and among the most important cellulose. Decoys based fibres are a natural product, obtained by grinding corn cob plus sticker attractants and other excipients. For now, on the market can be found in the form of pellets (manufacturer Natrocell Technologies, UK). The mechanism of action is based on the biological characteristic of cellulose to adopt water. After ingestion of bait, cellulose absorbs water and causes dehydration of the body, which causes a reduction in blood volume and blood pressure lowering, dry tissue and circulatory shock, and the end result leads to necrosis (Anonymous, 2005). It is believed that rodents do not develop resistance to cellulose. Also, it is equally effective in suppressing 
populations of resistant and non-resistant comensal rodents. No aversion causing rodents to bait based on cellulose. Decoys are fully biodegradable and have no pollution products that protect or environmental (Anonymous, 2005). Cellulose product so far been registered for use in communal hygiene. No information about their use of rodenticides in the field, besides the Jokic et al. (2006a,b, 2007), where efficiency was variable and ranged from $81.99 \%$ for the protection of alfalfa to $82.35 \%$ and $98 \%$ for wheat protection (Vukša et al., 2009). As the mechanism of action is based on the pulp tissue dehydration, reduced blood volume and blood pressure and stopping the circulation (Anonymous, 2005) is an important humidity of the environment (land) where applicable. This may be a limiting factor for their use.

\section{Conclusion}

In recent years, field rodents cause heavy damage to alfalfa and clover. The most abundant species are the common vole ( $M$. arvalis) and vole ( $A$. agrarius). Cyclic comes to reproduction of other rodents, especially hamsters $(C$. cricetus $)$. The irrigated water damage can cause $(A$. terrestris $)$ and ground voles $(P$. subteraneus). In order to suppress field rodents are necessary preventive measures and, quite often, prevention using rodenticides. Based on preventive care makes creating less favorable conditions for their overgrowth (destruction of food supplies, habitat disturbance and development, emphasizing the role of predatory, control is based on the application of classical acute rodenticide and anticoagulant, relevant and acute rodenticides based on vitamin D3 and it is a trace element. As the active ingredient cholecalciferol (vitamin D3) was placed on the list of limited and will be used only until end of 2013, be good to find new environmentallyfriendly substances, acute rodenticides. Should consider the possibility of product use cellulose based, natural substances, especially for fields that border the forest habitats and forest habitats themselves because there are only permitted to use products based on natural substances. The introduction of these products in use is necessary to improve their formulations, including impregnation that could be applied to wetlands.

\section{Acknowledgment}

Our research is funded by the Ministry Education, Science and Technological Development of the Republic of Serbia within the project III 46008 "Development of integrated management system harmful organisms in crop production in order to overcome resistance and improve the quality and safety of food." 


\title{
Opravdanost primene i pravci razvoja nekonvencionalnih rodenticida u zaštiti lucerke od glodara
}

\author{
M. Vukša, G. Jokić, S. Đedović, P. Vukša, B. Stojnić
}

\section{Rezime}

U radu su prikazani štetni glodari u usevima lucerke u Srbiji u prvoj deceniji ovog veka. Dat je i pregled registrovanih preparata, uz ocenu efikasnosti klasičnih (akutnih) rodenticida, antikoagulanata i rodenticida na bazi ekološki povoljnih aktivnih supstanci.

Pored antikoagulanata I i II generacije, čiji se mehanizam delovanja zasniva na sprečavanju sinteze faktora koagulacije krvi, u svetu su osamdesetih, a kod nas devedesetih godina prošlog veka uvedeni preparati na bazi vitamina $\mathrm{D}_{3^{-}}$holekalciferol. Njihov mehanizam delovanja je zasnovan na mobilizaciji kalcijuma iz kostiju i tkiva i kalcifikaciji krvnih sudova bubrega, jetre, srčanog mišića zbog čega dolazi do zastoja u radu ovih organa. Poslednje decenije prošlog veka registrovani su i preparati na bazi oligoelementa selena (Se) čiji se mehanizam delovanja zasniva na zameni SH grupa funkcionalnih enzima S-S grupama.

Pored toga, prikazana su ispitivanja mogućnosti primene ekološkog preparata na bazi celuloze u polju. U svetu su, do sada, registrovani samo za suzbijanje glodara u komunalnim objektima. Njegov mehanizam delovanja zasnovan je na interferenciji sa apsorpcijom vode što dovodi do dehidratacije $u$ glodara.

Glodari ne razvijaju rezistentnost na preparate na bazi vitamina $\mathrm{D}_{3}$ i selena, a preparat na bazi celuloze je povoljan sa toksikološkog i ekotoksikološkog stanovišta.

\section{References}

ANONYMOUS (2005): Sigurnosna lista Natromouse. Pinus TKI d.d., Rače, Slovenija.

BARCELOUX D.G. (1999): Selenium. Clin Toxicol, 37, 145-172.

BABINSKA-WERKA J. (1979): Effects of common voles in alfalfa crops. Acta Theriologica 24, 281-297.

BROWN D.G., BURK R.F., SEELY R.J., KIKER K.W. (1972): Effect of dietary selenium on the gastrointestinal absorption of $75 \mathrm{SeO} 3$ in the rat. Int. J. Vitam. Nutr. Res., 42, 588-591.

BROOKS E.J., ROWE P.F. (1987): Commensal Rodent Control, World Health Organization, WHO/VBC/87.949, 44-49. 
BUCKLE A.P. (1994): Rodent Control Methods: Chemical: p. 127-160 In: AP Buckle, RH Smith (eds.), Rodent pests and their control. CAB International, Wallingford, UK.

BYKOVSKI V.A., KANDIVIN N.V. (1988): Biomedical principles, development and perspectives of the use of bacteria and viruses. In: Rodent Pest Management, Ishwar Prakash Boca Ratón, Florida: CRC, Press, INC, 378-388.

ČAMPRAG D. (1980): Štetočine pšenice, raži, ječma i ovsa i njihovo suzbijanje. Poljoprivredni fakultet, Institut za zaštitu bilja »Dr Pavle Vukasović«, Novi Sad.

DUNĐERSKI Z., VUKŠA M. (1986): Mogućnost uvođenja alfa-hlorhidrina (Rattisterila) za suzbijanje poljskih voluharica. Četvrti Jugoslovenski simpozijum o zaštiti bilja i Jugoslovensko savetovanje o primeni pesticida, Opatija. Glasnik zaštite bilja, 10-11, 391.

DUNĐERSKI Z., VUKŠA M. (1987a): Control of vole population by alphachlorohydrin: laboratory and field tests. Proceedings of Conference on rodents EPPO and FAO, Roma, Italy, 146-149.

DUNĐERSKI Z., VUKŠA M. (1987b): Rattisteril - rodenticid - hemosterilant: Novi pristup u komunalnoj deratizaciji. Zbornik radova $\mathrm{V}$ simpozijuma DDD u zaštiti zdravlja ljudi, Beograd, 127-129.

ĐUKIĆ N., HORVATOVIĆ A., KATARANOVSKI D., MALETIN S., MATAVULJ M., PUJIN V., SEKULIĆ R. (2005): Poljoprivredna zoologija sa ekologijom, I Filozofija prirode, opšta zoologija i sistematika životinja. Poljoprivredni fakultet, Novi Sad, 524-528.

ENDOPOLS S. (2002): Rodenticides - indispensable for safe food production. Pestic. Outlook, 13, 231-232.

ERICKSON W., URBAN D. (2004): Potential Risk of Nine Rodenticides to Birds and Nontarget Mammals: A Comparative Approach, United States Environmental Protection Agency Washington, D.C., USA.

EU Wildlife and sustainable farming project (2009): Hamster - Crticetus cricetus factsheet.

ESPINO R, MONTERO G, VILLAFANA F, BORNOTE JG. (1986): Normas técnicas para la producción de Salmocumarín en Cuba. Bol Hig Epidemiol, 4, 1-25. FRENKEL G.D., FALVEY D. (1988): Evidence for the involment of sulfhydryl compounds in the inhibition of cellular DNA synthesis by selenite. Mol. Pharmacol., 34, 4, 573-577.

FRENKEL G.D., FALVEY D. (1989): Selenotrisulfide inhibits initiation by RNA polymerase II bot not elongation. J. Inorg. Biochem., 35, 3, 179-189.

GLAMOČLIJA, N.Đ. (1997): Ratarstvo.Univerzitet u Beogradu, Beograd, 11-33. HADLER M.R., BUCKLE A.P. (1992): Forty five years of anticoagulant rodenticides-past, present and future trends. Proceedings of the Fifteenth Vertebrate Pest Conference. Nebraska, Lincoln, USA.

HRGOVIĆ N., VUKIĆEVIĆ Z., KATARANOVSKI D. (1991): Deratizacija: Suzbijanje populacija štetnih glodara, Dečje novine, Gornji Milanovac. 
HUSINEC S., PAVKOV S., RATAJAC R. (2002): Synthesis and determination of acute toxicity of bromadiolone salt. 3rd International Conference of tghe Chemical Societi on the Soth-East European Countries on Chemistry in the New Millennium an Endless Frontier, September 22-25, 2002, Bucharest, Romania. Book of Abstracts.

JACOB J. (2003): Short-term effects of farming practices on populations of common voles. Agr.Ecosyst. Environ., 95, 321-325.

JANJIĆ V., ELEZOVIĆ I. (2010): Rodenticidi u knjizi: Pesticidi u poljoprivredi i šumarstvu u Srbiji (sedamnaesto dopunjeno i izmenjeno izdanje) Društvo za zaštitu bilja, Beograd, pp. 155-170.

JAĆEVIĆ M.V., MILOVANOVIĆ Z.A., JELIĆ K.A., ZOLOTAREVSKI LD., STANKOVIĆ D.A., BOKONJIĆ R.D., MILOSAVLJEVIĆ I.M. (2006): Cardiotixic effects of sodium selenite in rodents. Toxicology Letters, 164,189. JAĆEVIĆ V., JOKIĆ G., DRAGOJEVIĆ-SIMIĆ V., BOKONJIĆ D., VUČINIĆ S., VUKŠA M. (2011): Acute Toxicity of sodium selenite in Rodents: Pathomorphological Study. Millitary Medical Science Letters, 80, 90-96.

JELKS K.B., MILLER M.G. (2001): $\alpha$-Chlorohydrin inhibits glyceraldehyde-3phosphate dehydrogenase in multiple organs as well as in sperm. Toxicol Sci., 62, $1,115-123$.

JOKIĆ G., VUKŠA M., ĐEDOVIĆ S. (2006a): Efficacy of a cellulose-based product in controlling house mouse (Mus musculus) in agricultural storage facilities. Proceedings of the $9^{\text {th }}$ International Working Conference on Stored Product Protection, Campinas, São Paulo, Brazil, 677-680.

JOKIĆ G., VUKŠA M., ĐEDOVIĆ S. (2006b): Suzbijanje hrčka (Cricetus cricetus) u usevu pšenice mamcima na bazi cink-fosfida. Zbornik rezimea VIII savetovanja o zaštiti bilja, Zlatibor, 38 .

JOKIĆ G., VUKŠA M., ĐEDOVIĆ S. (2007): Efficacy of rodent control in alfalfa and wheat crops using chemical and natural rodenticides. Pesticidi i fitomedicina, 22, 241-246.

JOKIĆ G., VUKŠA M., DRAGANIĆ M., ČOVIĆ I., ĐEDOVIĆ S. (2009a): Application of sodium selenite baits to control common vole microtus arvalis pall in alfalfa crops in Serbia. $7^{\text {th }}$ European Vertebrate Pest Management, 8-12 September, Lyon, France (Book of abstract).

JOKIĆ G., VUKŠA M., DRAGANIĆ M., ČOVIĆ I., ĐEDOVIĆ S (2009b): Laboratory examination of the efficacy of sodium selenite rodenticide against wild populations of Norway rat (Rattus norvegicus). IOBC/WPRS (OILB/SROP), Conference working group integrated protection of stoed products, June 29-July 2, Campobasso, Italy (Book of abstact).

JOKIĆ G., VUKŠA M., ĐEDOVIĆ S. (2009c): The effect of rodenticide baits containing $0.1 \%$ sodium selenite against commensal rodents Rattus norvegicus and Mus musculus at a milling facility IOBC/WPRS ( OILB/SROP), Conference 
working group integrated protection of stoed products, June 29 - July 2, Campobasso, Italy (Book of abstact).

JOKIĆ G., VUKŠA P., VUKŠA M. (2010a): Comparative efficacy of convencional and new rodenticides against Microtus arvalis (Pallas, 1778) in wheat and alfalfa crop. Crop Protection, 29, 5, 487-491.

JOKIĆ G., VUKŠA M., ELEZOVIĆ I., STOJNIĆ B., ĐEDOVIĆ S. (2010b): Efikasnost različitih formulacija rodenticida na bazi bromadiolona u suzbijanju štetnih glodara u lucerki, Pesticides and Phytomedicine, 25, 3, 277-282.

JONES AR (1983): Antifertility actions of alpha-chlorohydrin in the male. Aust J Biol Sci, 36, 333-350.

JONES A.R., COOPER T.G. (1999): A re-apprasial of the post-testicular action and toxicity of chlorinated antifertility compounds. Int. J. Androl., 22, 3, 130-138.

KALLA N.R., CHOHAN K.S. (1980): Studies on mechanism of action of alphamonochlorohydrin. Experimentelle Pathologie, 18, 7-8, 430- 437.

KAMRIN A.M. (1997): Triazines and Triazoles in: Pesticide profiles. Toxicity, Environmental Impact and Fate CRC, Lewis publishers, Boca Raton, New York.

KATARANOVSKI D., KATARANOVSKI M. (1997): Second generations rodenticides: Comparative study. Proc. Intern. Symp.Pestic. Publ. Health, Budva. Plamary lect. Arch. Toxicol. Kinet. Xenobiot. Metab., 5, 2, 91-99.

KEREŠI T., SEKULIĆ S. STAMENKOVIĆ S. (2005): Pojava važnijih štetočina ratarskih biljaka u Vojvodini 2004. i prognoza pojave 2005. godine, Biljni lekar, 1, 35-43.

KINDER D.S., COLESTOCK C.N., RAZNIAK S.L., Hogan G.R. (1988): TimeDependent Distribution of sodium Selenite in the Female ICR Mouse Classification Code: 1915. Bulletin of Environmental Contamination and Toxicology, 40, 425432.

LUND M. (1988) : Flocoumafen - A New Anticoagulant Rodenticide. Proceedings of the Thirtheenth Vertebrate Pest Conference. Paper 12, 1988.

MARCH R.E., HOWARD W.E. (1970): "Chemosterilants as an approach to rodent control". Proceedings of the 4th Vertebrate Pest Conference. Paper14.

http: //digitalcommons.unl.edu/vpcfour/14

MEEHAN A.P. (1978): Rodenticidal activity of bromadiolone - a new anticoagulant. Proceedings of the $8^{\text {th }}$ Vertebrate Pest Control: 122-126.

MIKEŠ M., HABIJAN-MIKEŠ V. (1986): Stacionarna istraživanja sitnih sisara u Vojvodini. Godišnjak Biološkog Instituta, 39, 81-94, Novi Sad.

MIŠIĆ S., VUKŠA M., SIMIĆ D. (1991): Ispitivanje genotoksičnih efekata alfahlorhidrina i trihlorfona metodom E.Coli multitesta. Pesticidi, 6, 79-84.

MYLLYMAKI A.. (1977): Outbreaks and damages by the field vole Microtus agrestis (L.), since World War II in Europe. EPPO Bull., 7, 177-207.

EPPO (2004): Guideline for the efficacy evaluation of rodenticides; Field tests against synanthropic rodents (Mus musculus, Rattus norvegicus i $R$. rattus) - PP 1/114(2), in: EPPO Standards: Guidelines for the efficacy evaluation of Plant 
Protection Products, Rodenticides, 1, European and Mediterranean Plant Protection Organization, Paris, pp. 83-144.

PARK Y.-C., WHANGER P.D. (1995): Toxicity, Metabolism and Absorption of selenite by Isolated Rat Hepatocytes. Toxicology, 100, 151-162.

PETROV B., RUŽIĆ A. (1985): Taxonomy and distribution of members of the genus Mus(Rodentia, Mammalia) in Yugoslavia. Zbornik radova o fauni SR Srbije, knj. 3, 209-243. Srpska akademija nauka i umetnosti, Odeljenje prirodnomatematičkih nauka, Beograd.

PLETNIKOVA I.P. (1970): Biological action and the non-injuriousness level of selenium when it enters the organism together with drinking water [in Russian, English summary]. Gig. Sanit. 35, 14-19.

PRAKASH I. (1988): Bait shyness and poison aversion. In : Prakash I. (ed). Rodent Pest Memagment. CRC Press. Boca Raton. pp 321-329.

ROBERTS T.R., HUTSON D.H. (1999): Insecticides and Fungicides. The Royal Soc Chem. Cambridge, UK: Metabolic Pathway of Agrochemicals.

RUŽIĆ A. (1983): Glodari (Rodentia).U knj.: Priručnik PIS, 151-167. Savez društava za zaštitu bilja Jugoslavije, Beograd.

RADOVIĆ J., SOKOLOVIĆ D., MARKOVIĆ J. (2009): Alfalfa most important perennial forage legume in animal husbandry. Biotechnology in Animal Husbandry, 25, 5-6, 465-475.

REPUBLIČKI ZAVOD ZA STATISTIKU (2011): Poljoprivreda (deveto poglavlje). Statistički godišnjak Republike Srbije.str.127-224.

RYSZKA F. DROZDZ M. DOLINSKA B. ZIENTARSKA G and SZULC B (1994): Pharmacokinetics and distribution of selenium in blood and organs of rats. Pharmazie 449, 47-48.

SCHACHTER A. (1998): Roedenticida cubano causa asombro (monograph on the Internet). La Havana, Cuba:Organizacion de Estados Iberoamericanos;1998 (cited 2002 Sep.12) Avaliable from:http:www.oei.org.co./sii/entrega 5/arto5.htm

Philippine experimental rice fields. Int. Biodeter. \& Biodegr., 49, 125-132.

SINGLETON G.R., HINDS L.A., LEIRS, H., ZHANG Z.(1999): Ecologically based rodent menagment ACIAR, Canberra, Australia.

SMITH M.H., GARDNER R.H., GENTRY, I.B., KANFMAN B.W., OFAREL M.R. (1975): Density estimations of small mamal population. In: Small Mamals: Their productivity and population Dynamics IPB (5). Ed Galley, T.B., Petrusewich, K. and Ryszkowski, L., 25-55.

STENSETH N.C., LEIRS H., SKONHOFT A., DAVIS S.A., PECH R., ANDREASSER H.P., SINGLETOON G.R., LIMA M., MACHANGU R.M., MAKUNDI R.H., ZHANG Z., BROWN P.B., SHI D., WAN X.(2003): Mice and rats: The dynamics and bio-economics of agricultural rodents pests. Front Ecolo. Environ., 1, 7. (Online http://www.frontiersinecology.org)

SUNG-HWAN K., IN-CHUL L, JEONG-HYEOUN L., CHANGJOUNG M., CHUN-SIK B., SUNG-HO K., DONG-HO S., HYOUNG-CHIN K., JONG- 
CHOOH K. (2012): Spermatotoxic effects of $\alpha$-chlorohydrin in rats Lab Anim Res., 28, 1, 11-16.

ŠTRBAC, P., KONSTANTINOVIĆ., B., KLOKOČAR-ŠMIT, Z., DRAŽIĆ, D.(1996): Zaštita lucerke od štetočina, bolesti i korova. Feljton, Novi Sad.

TOSCHIGUIN Y. (1979): Evaluación comparativa de algunos métodos de hallazgo de ratas grises para la determinación de la efectividad de la desratización. Problemas de las infecciones especialmen te riesgosas. Rev Desinfección Desratización Desinsectación (DDD), 2, 222-24.

VUKŠA M., FORGIĆ G. (2003): Problemi u suzbijanju glodara i uvođenje ekološki pogodnih preparata. Zbornik rezimea VI Savetovanja o zaštiti bilja, Zlatibor, 29.

VUKŠA M. (2005): Štetni glodari u lucerki i detelini i njihovo suzbijanje. Biljni lekar r.5 (posvećen zaštiti lucerke i deteline), 549-557.

VUKŠSA M., FORGIĆ G. (2006): Problem glodara u njivskoj i biljnoj proizvodnji sa posebnim osvrtom na 2006. godinu. Zbornik rezimea VIII savetovanja o zaštiti bilja, Zlatibor, 12.

VUKŠA M., DRAGANIĆ M., ĐEDOVIĆ S., JOKIĆ G. (2006): Laboratory effects and efficacy of an Se-based rodenticide in controlling rodents in storage facilities. Proceedings of the $9^{\text {th }}$ International Working Conference on Stored Product Protection, Campinas, São Paulo, Brazil, 920-925.

VUKŠA M., JOKIĆ G., ĐEDOVIĆ S. (2009): IPM strategy for rodent control in alfalfa crops. 9th International Symposium - Modern Trends in Livestock Production - Biotechnology in Animal Husbandry, 25 (5-6), 2, 1241-1248.

VUKŠA M., FORGIĆ G., RADONIĆ K. (2010): Štetni glodari u lucerki i strnim žitima i njihovo suzbijanje. Biljni lekar, 2. 138-150.

WHO (1988): Phosphine and selected metalphosphides, IPCS, Environmental Health Criteria 73, WHO,Geneva . 